
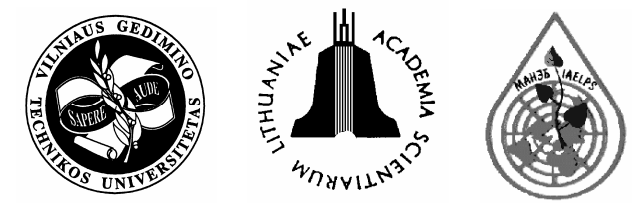

\title{
INVESTIGATION AND EVALUATION OF SURFACE WATER POLLUTION WITH HEAVY METALS AND OIL PRODUCTS IN KAIRIAI MILITARY GROUND TERRITORY
}

\author{
Raimondas Leopoldas Idzelis, Kristina Greičiūtė, Dainius Paliulis \\ Dept of Environmental of Protection, Vilnius Gediminas Technical University, \\ Sauletekio al. 11, LT-10223 Vilnius, Lithuania. \\ E-mail: kristina.greiciute@ap.vtu.lt \\ Submitted 12 Sept 2005; accepted 10 Oct 2006
}

\begin{abstract}
Water pollution with heavy metals, oil and its products is a very important environmental problem. Major part of chemical elements penetrating into the environment gets accumulated in the soil and bed sediment of water bodies. They may also migrate into surface, ground and underground water and spread at great distances. From here, they may enter again nutritional chains and poison living organisms. It is very important and necessary to investigate military territories and evaluate their environmental condition in order to identify the works of their cleaning and optimization of their environmental condition as well as their scope. However, not all the military territories in Lithuania have been sufficiently investigated so far, damage to the environment is not known. Therefore, investigation of such territories is of utmost importance, it is of scientific and environmental significance. This work is dedicated to the investigation and evaluation of surface water and bed sediment pollution with heavy metals and oil products in one of the biggest military grounds of Lithuania - Kairiai Military Ground. Results of the investigation allowed answering the main questions about the most common pollutants, spreading in the environment because of military activities, to determine the level of pollution and most vulnerable territories.
\end{abstract}

Keywords: military grounds, surface water bodies, pollution, heavy metals, oil products, bed sediment.

\section{Introduction}

The most vivid trace in the use of Lithuanian nature for military purposes has been left by military units of the Soviet Union. During the period of the soviet army's stay in Lithuania the country had 277 military areas of the Soviet Union (now Russian Federation) with 462 military units deployed on them. They covered the total area of 67762 ha or 1,04 percent of the area of Lithuania [1]. The first Soviet military areas were established on the sites of the old military units. New military areas developed in two directions:

- new areas were annexed to the old areas;

- territories never used for military purposes were reclaimed.

The expansion of natural areas used for military purposes was not accompanied by any environmental requirements. Ecological conditions were not taken into consideration. After withdrawal of the soviet army 6 military grounds were established in Lithuania. Their use was approved by the Government. The following are the largest military grounds of Lithuania: the central military ground of the Lithuanian army in Pabrade, military grounds in Gaižiūnai (Jonava region) and Kairènai (Klaipeda region). Each military area consists of two parts: exercise areas of full use and limited use. Military areas of full use are land plots given to the Ministry of
National Defence with the property rights. Such areas have special stationary structures necessary for exercises, defence infrastructure; moreover, exercises involving shooting real cartridges are held and heavy military war materials are used there. Military areas of limited use are land plots (usually those of forests) given to the military forces of Lithuania and used for training military staff without changing the direct purpose of the land (forestry) [1-2]. Military grounds are ussually situated in sequestered forested areas, far enough from towns or bigger settlements. Ussualy such territories are noted for their valuable landscape, rare and vanishing species with a high environmental value. Though military activities affect not only the environment of military grounds and surrounding areas, but in some cases can be harmfull to human health because of different pollutants left in the soil or water. It is reasonably thought till now that in the former soviet military grounds, because of their specific purpose and frequent use of military equipment and different munitions, big anomalies of pollution with heavy metals and oil products are met. Because of continuous damages, made to the top soil, vegetation is very scarce, in some spots missing - sandy wastelands are formed. Furthermore, different kinds of military settlements with living houses, households, transport and equipment maintenance etc were located in the territories of military grounds. Scientific research has shown that wastewater 
from fields, used for military vehicle and equipment washing and maintenance, is usually polluted with big amounts of different chemical substances, and poses a danger to pollute the environment [3]. Military activities have a big negative impact on the environment. It can be physical and chemical. Physical impacts include different damages, like deforestation, destruction of the soil structure, disturbance of natural flora and fauna, etc. Chemical impacts involve pollution with different chemical substances, waste of military industry, etc [4]. It is necessary to note other patterns of impact on the environment by military activities. Soils and landscapes suffer from physical and chemical impacts of military activities [4, 5]. Very often military grounds are established in recreational or even state-protected areas which are noted for their important ecological functions [5-8]. Thus areas of recreational zones decline, lots of land and forest properties are lost. Military activities damage unique communities of biota, disrupts animal migration rutes, disturbs their comfort [5, 6]. Kairiai Military Ground is situated near the Curronian Lagoon, approximately $7 \mathrm{~km}$ south from the center of Klaipeda. Some objects of the city are very close to the limits of Kairiai Military Ground. The present territory of Kairiai Military Ground is of 3700 ha, but there is a lack of information about its history [9-12]. Kairiai Military Ground was established shortly after the World War II in 1948. Like all the other territories of the soviet army it was a closed military object with a special security regime, inaccessible for citizens and scientists. Thus there was not enough information about military trainings, their extent and impacts on the environment in the Military Ground. In 1993 Kairiai Military Ground was taken under the command of a newly-created Lithuanian army. Some military objects and fields had been left quite in a good condition, thus after small technical repair shooting ranges, motorfields and fields of tactical training were used by the Lithuanian troops. During soviet times the shooting range covered the central part of Kairiai Military Ground. The motorfield was in the northern part of the territory and covered 76 ha. There were roads and overhead roads, other smaller equipment for improving driving skills [10, 13]. Also, in Kairiai Military Ground there was a tank directrix, which covered 319 ha of area - a $4 \mathrm{~km}$ route between Klaipèda Channel and the villages of Vaškiai and Lūžgaliai. Furthermore, in the territory of Kairiai Military Ground there was a position of antiaircraft and missile division, a command post, barracs. There were six missile sites, two airsheds and a small petrol station. The territory of Kairiai Military Ground had a dence net of communication. In the central part of the Military Ground, in a particularly protected airshed, there was a missile which had a particular destination [13, 14]. All these activities had a great impact on the environment.

The aim of the work is to analyse and evaluate pollution of surface water bodies, situated in the territory of Kairiai Military Ground, with heavy metals and oil products, relying on the investigation results.

\section{Investigation methodology}

In recent decades human economic activities were increased and intensified. It negatively affected ecosystems and processes of natural self-regulation. Waste water is the main reason of ground and surface water pollution. Pollutants are biologically active components, and they have such characteristics as long period of persistence, multiplex migration from water to sediments and backwards, effect of bioaccumulation in the biota and food chain [13-15]. Such factors change the living environment of water species and lead to damages of functional condition of organisms. It is revealed that even small concentrations of pollutants change activity of ferments, take part in nucleic circulation and protein synthesis, opiate immunological reactions, invoke changes in genetic material. Military activities, performed in military grounds, pose danger not only to pollute the soil layer, but also water bodies which are often used for training needs [16-18]. It is necessary to note that heavy metals present in the water eventually settle on the bed of a water body and accumulate in its sediment. In the water of polluted water bodies not only big concentrations of heavy metals, but also of oil products are often met [17-19]. Because of the fact that oil products are easier than water, they uprise to the surface of water. That is why pollution of sediment with oil products was not investigated [20-22].

With the aim of determining the pollution of water and sediment, 14 samples of water and 12 samples of sediment were taken. Samples were taken in 4 objects in Kairiai Military Ground: 1 sample was taken from the well with drinking water near the barracks; 1 sample from the abandoned well near the shooting range; 6 samples of water and 6 samples of sediment were taken from the Channel of King Vilhelm; 6 and 6 samples - from the lakelets near the motorfield (Fig 1). Samples of water and sediment were taken in September, and on the same day brought to the laboratory for analysis. The air temperature ranged from $+9{ }^{\circ} \mathrm{C}$ at 9 a. m. to $+18{ }^{\circ} \mathrm{C}$ at $2 \mathrm{p}$. m. At the point of sampling water samples were scooped using a plastic scoop (for analysis of heavy metals) and a glass vessel (for analysis of oil products). Samples from the water bodies with slack-water were taken at a depth of $20 \mathrm{~cm}$ (but not less than $10 \mathrm{~cm}$ from the bed), while those from the Channel - in the flow of water. For the removal of large additions (like algae, remnants of plants, etc) water was filtered using a $0,5 \mathrm{~mm}$ diameter sieve. After filtration water was pulled into plastic (for heavy metal analysis) and glass (for oil product analysis) bottles. The initial volume of a sample was 11 .

For the collection of sediment, every $50 \mathrm{~m}$ an entire sample was formed from some point samples taken in still places of the Chanel or lakelets with minimal additives. Sediment was collected using a special glass shovel. After removal of plant remnants and other additives, samples were poured into textile bags and dried, assuring that the bags had no contact, and that water from one sample could not wash the other ones. The initial 
Background and maximum allowed heavy metal concentrations in surface waters and bed sediment

\begin{tabular}{c|c|c|c}
\hline Element & $\begin{array}{c}\text { Background concentrations in } \\
\text { surface waters, } \mathrm{mg} / \mathrm{l}\end{array}$ & $\begin{array}{c}\text { Maximum allowed concentrations } \\
\text { in surface waters, } \mathrm{mg} / \mathrm{l}\end{array}$ & $\begin{array}{c}\text { Background concentrations in } \\
\text { bed sediment, } \mathrm{mg} / \mathrm{kg}\end{array}$ \\
\hline $\mathrm{Cr}$ & 0,005 & 0,05 & 30,00 \\
\hline $\mathrm{Zn}$ & 0,03 & 3,00 & 26,00 \\
\hline $\mathrm{Mn}$ & 0,045 & 0,2 & 427,00 \\
\hline $\mathrm{Cu}$ & $<0,005$ & 2,00 & 8,10 \\
\hline $\mathrm{Ni}$ & $<0,008$ & 0,02 & 12,00 \\
\hline $\mathrm{Pb}$ & 0,001 & 0,025 & 15,00 \\
\hline Oil products & - & 0,3 & - \\
\hline
\end{tabular}

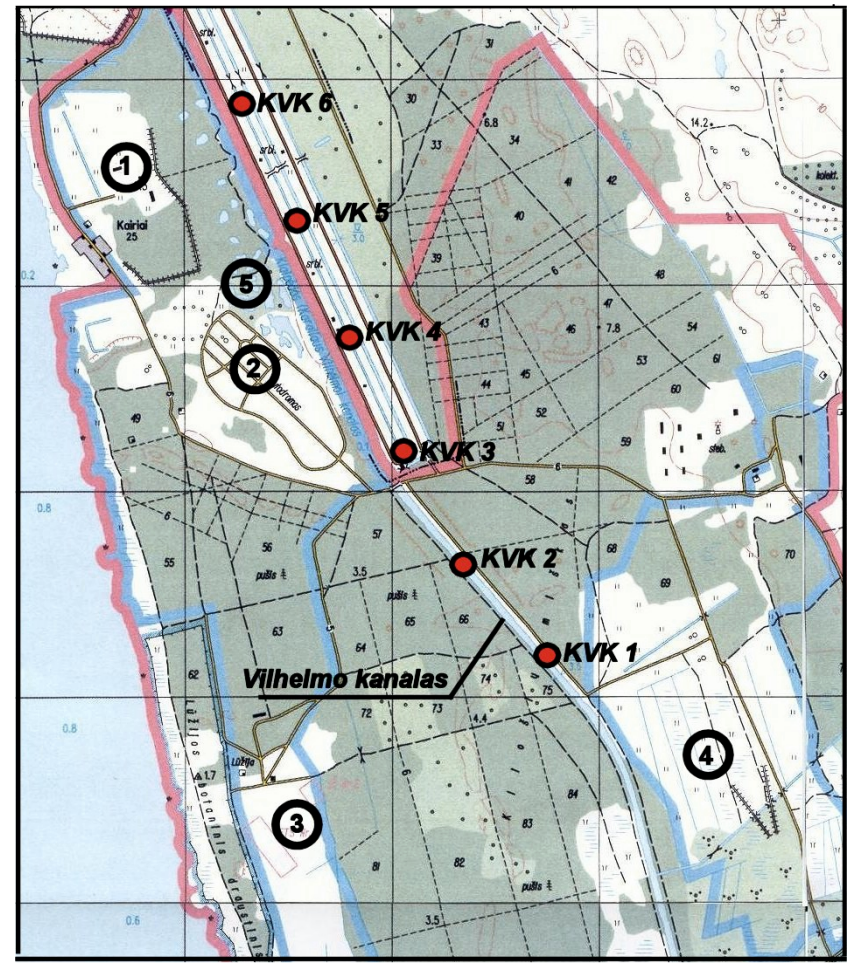

Fig 1. Situation plan of Kairiai Military Ground: 1 - abandoned military settlement, 2 - motorfield, 3 - shooting ranges, 4 - pine forest, 5 - lakelets. Clipping KVK1-6 points of water and sediment sampling in King Vilhelm Channel

weight of a sample was $800 \mathrm{~g}$. The results of water and bed sediment analysis were compared with valid in Lithuania maximum allowed concentrations (MAC) regulated by the Norms of Hygiene, and with background concentrations (Table).

\section{Investigation results}

During analysis of the 14 water samples, taken from surface water bodies situated in the territory of Kairiai Military Ground, compounds of chromium were detected only in the water from King Vilhelm Channel, while the other investigated water bodies were not polluted with chromium. It was estimated that the concentrations of chromium ranged from 0,022 to $0,0029 \mathrm{mg} / \mathrm{l}$ and medium concentration was $0,00285 \mathrm{mg} / \mathrm{l}$ (while MAC is $0,05 \mathrm{mg} / \mathrm{l}$ ) (Fig 2). Such results show that surface water bodies situated or flowing through the territory of Kairiai Military Ground are not polluted with chromium compounds. However, chromium concentrations detected in the water of King Vilhelm Channel shows that there is some source of pollution. Chromium compounds are common in fuel and fat composition, so it is possible that pollution resulted from military vehicle riding, washing, etc. It is also possible that pollution is not related with military activities, as the water in the Channel flows from the city side. As it is seen in Fig 2, the biggest concentration of chromium was detected at point $\mathrm{kvk} 4$ which is very close to the motorfield. It cannot be stated very clearly, but it might be that pollution with chromium at point kvk4 is related with activities performed in the motorfield.

During analysis of the 14 water samples zinc concentrations were detected only in the water of lakelets. They ranged from 0,042 to $1,017 \mathrm{mg} / 1$ (Fig 3). Medium concentration of zinc was $0,248 \mathrm{mg} / \mathrm{l}$, and it was 8 times bigger than the background one (background concentration of zinc was $0,03 \mathrm{mg} / \mathrm{l}$ ). Two samples of water had zinc concentrations 33 and 10 times bigger than background (samples kev2 and kev5). Concentration of zinc in sample kev2 was $1,017 \mathrm{mg} / \mathrm{l}$, while MAC for zinc is $3,0 \mathrm{mg} / \mathrm{l}$. Such results allow us to state that surface waters in the territory of Kairiai Military Ground are not polluted with zinc compounds. Anyway concentrations of zinc in water samples kev2 and kev5 were some times biger than in the rest ones. It is known that the investigated lakelets are very often used for military vehicle riding and washing. Zinc is present in the composition of fuel and mashine fats, so it could easily get into water. Moreover, heavy metals can get into the soil or water because of friction between metal vehicle parts or between vehicle caterpillar tracks and ground. In the water of two investigated wells concentrations of zinc were tens of times bigger than the background one, but they didn't exceed MAC. It is necessary to state, that zinc is naturally present in the soil in comparably big amounts, so it can easily get into groundwater. Big concentrations of zinc in wells could occur because of natural processes.

During analysis of the 14 water samples, taken from surface water bodies, situated or flowing through the 
territory of Kairiai Military Ground, concentrations of manganese were detected only in the water of King Vilhelm Channel and lakelets. Manganese concentrations in samples taken from King Vilhelm Channel were in the range from 0,0092 to $0,0614 \mathrm{mg} / \mathrm{l}$ (Fig 4).

Medium manganese concentration was $0,032 \mathrm{mg} / \mathrm{kg}$, i e less than either background $(0,045 \mathrm{mg} / \mathrm{l})$ or MAC $(0,2 \mathrm{mg} / \mathrm{l})$. However, manganese concentrations in samples kvk2 and kvk5 exceeded the background limits. Manganese compounds can be met in natural clean water, as they are present in the soil composition. Anyway, the results when concentrations of manganese are bigger than background in some water samples show that there should be some source of pollution. It could be because of different military activities. It is hard to judge about the origin of pollution in sample kvk2 (where the concentration was bigger than background), as no particular activities are performed nearby. Talking about the position of water sampling point kvk5, it is near the lakelets (Fig 1). As it was said before, this territory is often used for military transport needs. It could be the source of pollution. Such a proposition can be confirmed by the results obtained while analysing water from lakelets. Determined manganese concentrations were comparably big and ranged from $0,0253 \mathrm{mg} / \mathrm{l}$ to $0,0732 \mathrm{mg} / \mathrm{l}$ (Fig 5). Medium manganese concentration in the water of lakelets was $0,073 \mathrm{mg} / \mathrm{l}$, i e 1,6 time bigger than background $(0,045 \mathrm{mg} / \mathrm{l})$. Anyway, MAC was not exceeded in any sample (MAC for manganese is $0,2 \mathrm{mg} / \mathrm{l}$ ). Manganese concentrations were bigger than background in water samples kev2, kev4 and kev5. It is important to note that in water samples kev2 and kev5 concentrations of zinc were also bigger than background. Such results allow us to state that lakelets are polluted with zinc and manganese. These metals can be found not only in fuel or machine fats, but also in ammunition and military vehicle parts. It is likely that military activities cause the pollution of lakelets in the territory of Kairiai Military Ground. The investigation results revealed that surface water bodies in the territory of Kairiai Military Ground were not polluted with copper, nickel or lead. Concentrations of these metals were not detected in the analysed water samples.

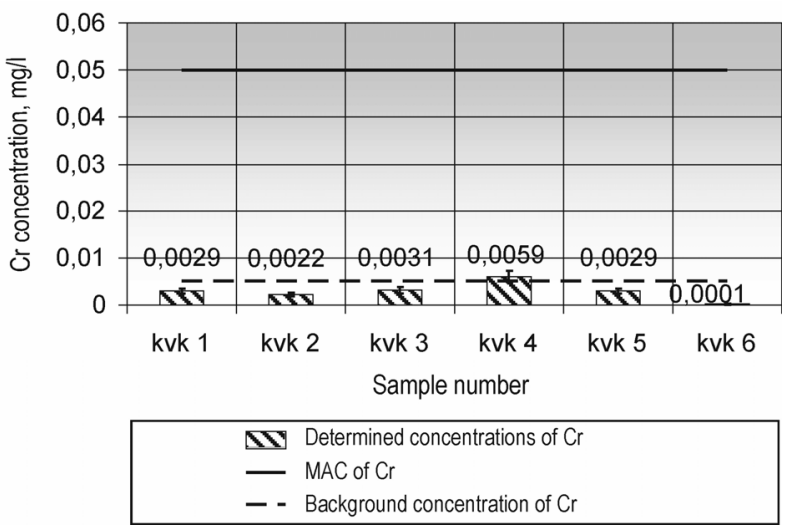

Fig 2. Chromium concentrations in the water of King Vilhelm Channel

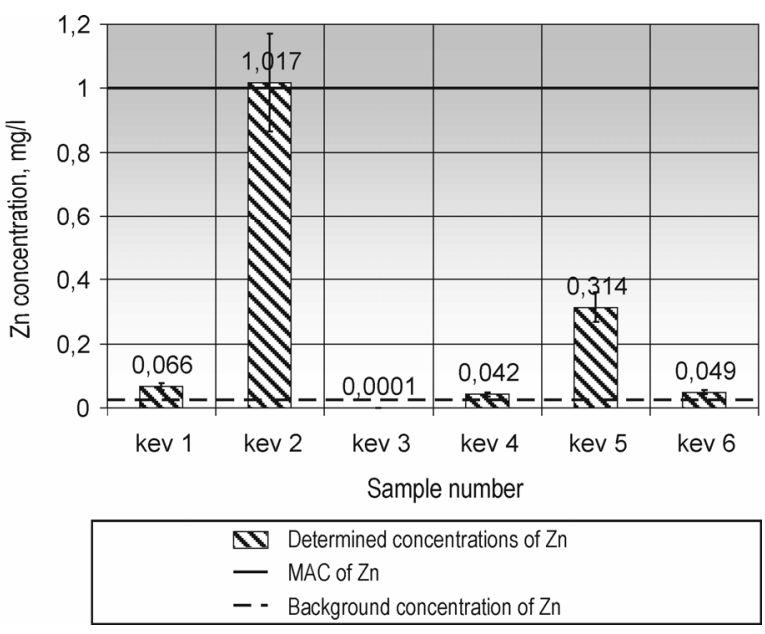

Fig 3. Distribution of zinc concentrations in the water of lakelets

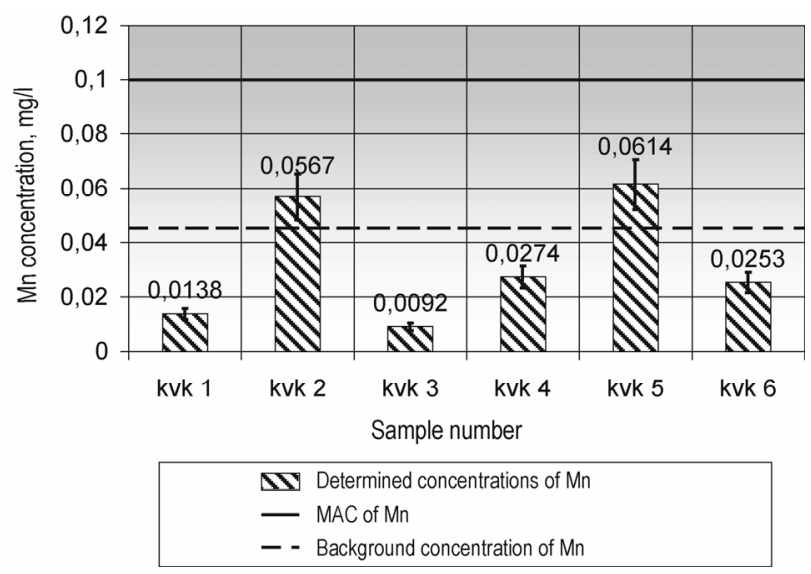

Fig 4. Distribution of manganese concentrations in the water of King Vilhelm Channel

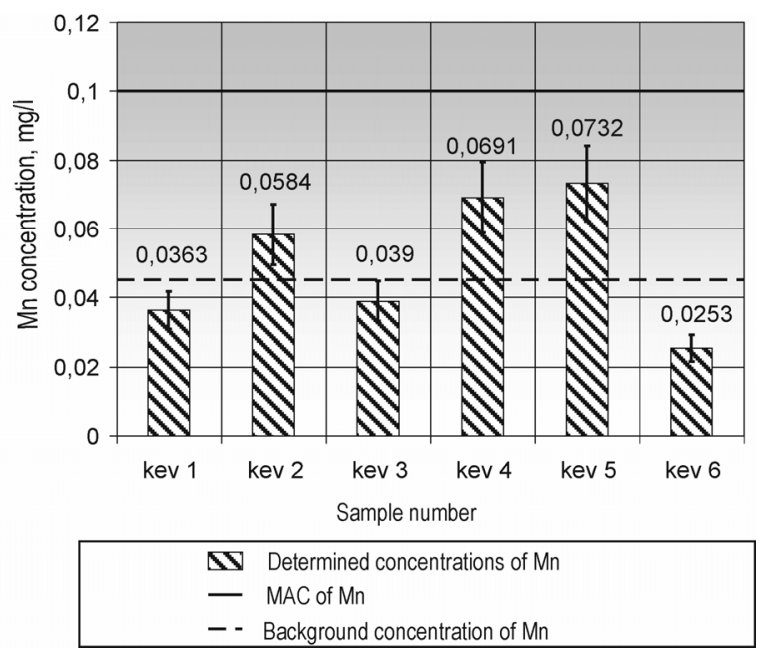

Fig 5. Distribution of manganese concentrations in the water of lakelets

Analysis of the 12 samples of bed sediment taken from lakelets and King Vilhelm Channel revealed that concentrations of manganese were in the range from 59,76 to $212,7 \mathrm{mg} / \mathrm{kg}$, while background concentration of 
manganese in bed sediment is $427,00 \mathrm{mg} / \mathrm{kg}$ (Fig 6). Medium determined manganese concentration in bed sediment of lakelets was $187,20 \mathrm{mg} / \mathrm{kg}$, and it was bigger than in bed sediment of King Vilhelm Channel $(118,76 \mathrm{mg} / \mathrm{kg})$. Even maximum determined concentration of manganese was twice smaller than background, so it can be concluded that bed sediment of water bodies situated in the territory of Kairiai Military Ground are not polluted with manganese. It is necessary to note that manganese concentrations were detected both in the water and bed sediment of King Vilhelm Channel and lakelets.

Manganese is present naturally in the soil, and its soluble part could easily get into water and bed sediment. Anyway, in some water samples manganese concentrations were bigger than background, so it could be because of military activities.

Bed sediment of water bodies, situated in Kairiai Military Ground, are not polluted with zinc compounds. Medium concentration of zinc in bed sediment of lakelets was $8,04 \mathrm{mg} / \mathrm{kg}$, and $13,87 \mathrm{mg} / \mathrm{kg}$ - in bed sediment of King Vilhelm Channel (Fig 7). Such concentrations are more than twice smaller than background concentration of zinc $(26,00 \mathrm{mg} / \mathrm{kg})$. Manganese concentrations in the water of King Vilhelm Channel were not detected during water sample analysis, while in some water samples taken from lakelets concentration of manganese was bigger than background. Such results allow to suggest that some time ago the water of King Vilhelm Channel was polluted with zinc, but then pollutants settled, leaving water comparably clean. The water of lakelets is still polluted, and that is why zinc concentrations were detected both in the water and bed sediment.

Analysis of the 12 bed sediment samples taken from the lakelets and the Channel of King Vilhelm revealed that concentrations of copper varied from 3,61 to $38,97 \mathrm{mg} / \mathrm{kg}$ (Fig 6). Medium concentration of copper in bed sediment of lakelets was $11,25 \mathrm{mg} / \mathrm{kg}$, while in bed sediment of King Vilhelm Channel it was 18,50 mg/kg (Fig 8). Background concentration of copper is $8,10 \mathrm{mg} / \mathrm{kg}$, so it is obviuous that even medium determined concentrations are bigger in the investigated samples. Copper concentrations determined in 2 samples taken from the Channel of King Vilhelm and 1 sample taken from lakelets were 3 times bigger than background. Only in 6 analysed samples copper concentrations were equal to background, and in the rest ones they were much bigger.

Copper concentrations were not determined neither in the water of King Vilhelm Channel nor in the water of lakelets. As in the case of zinc, it can be stated that the investigated water bodies were polluted with copper in the past, and pollutants accumulated in bed sediment. At present the pollution has stopped, and that is why copper compounds are no more present in the water of lakelets and King Vilhelm Channel.

Analysis of the 12 samples of bed sediment taken from lakelets and King Vilhelm Channel revealed that lead concentrations varied from 26,89 to $458,65 \mathrm{mg} / \mathrm{kg}$ (Fig 9).

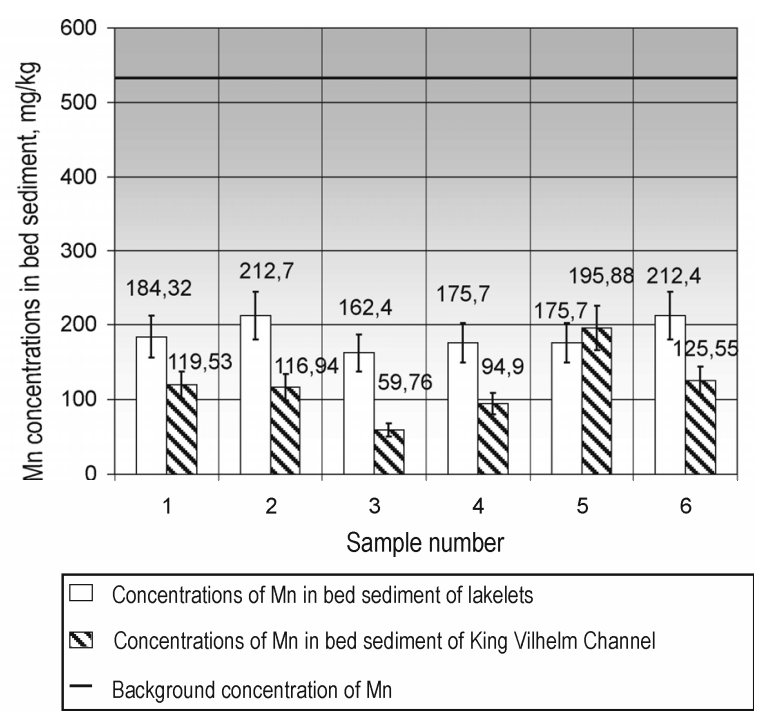

Fig 6. Manganese concentrations in the bed sediment of surface waters in Kairiai Military Ground

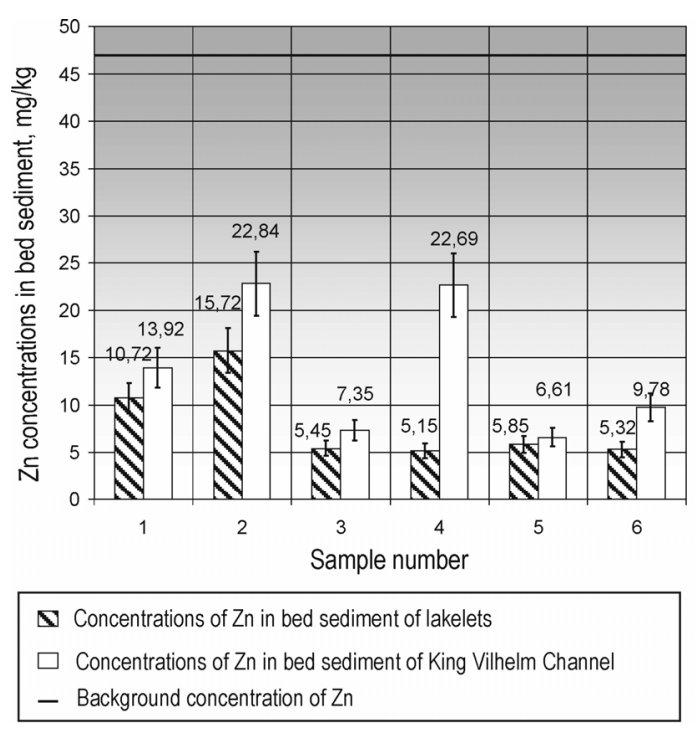

Fig 7. Zinc concentrations in the bed sediment of surface waters in Kairiai Military Ground

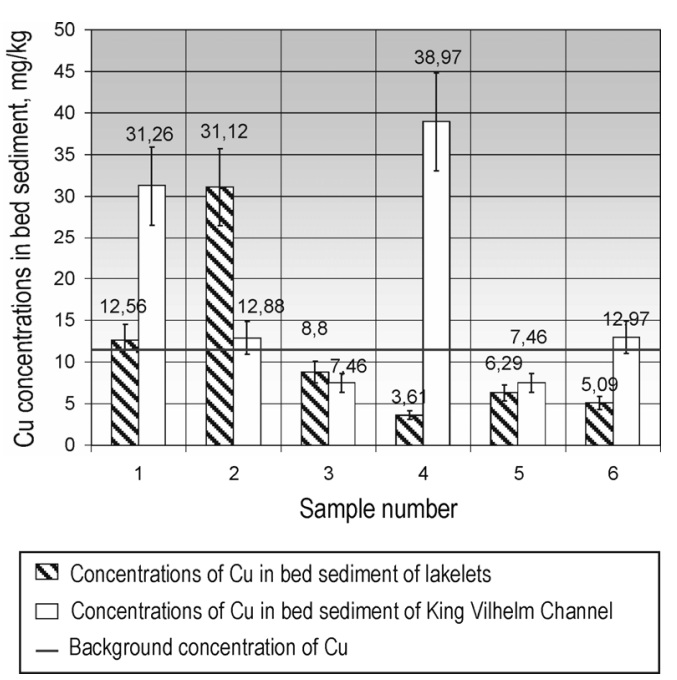

Fig 8. Copper concentrations in the bed sediment of surface waters in Kairiai Military Ground 


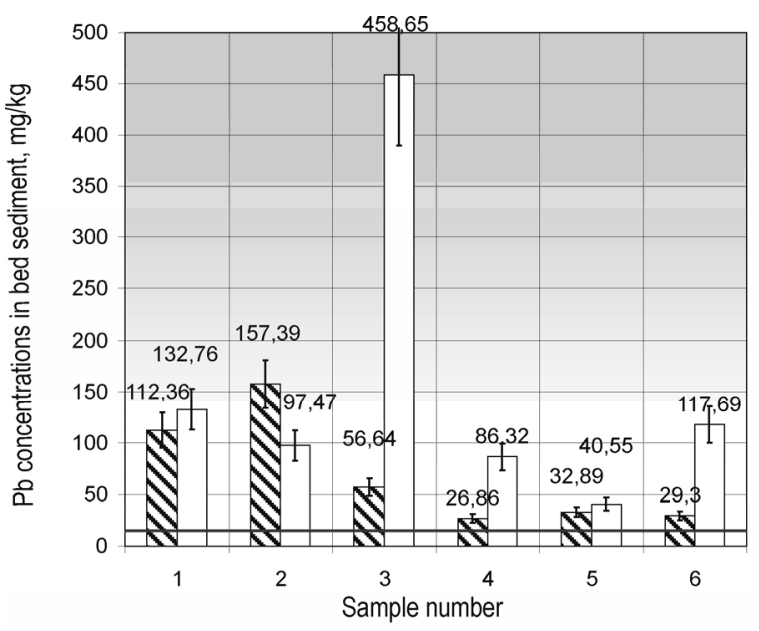

D. Concentrations of $\mathrm{Pb}$ in bed sediment of lakelets

$\square$ Concentrations of $\mathrm{Pb}$ in bed sediment of King Vilhelm Channel

- Background concentration of $\mathrm{Pb}$

Fig 9. Lead concentrations in the bed sediment of surface waters in Kairiai Military Ground

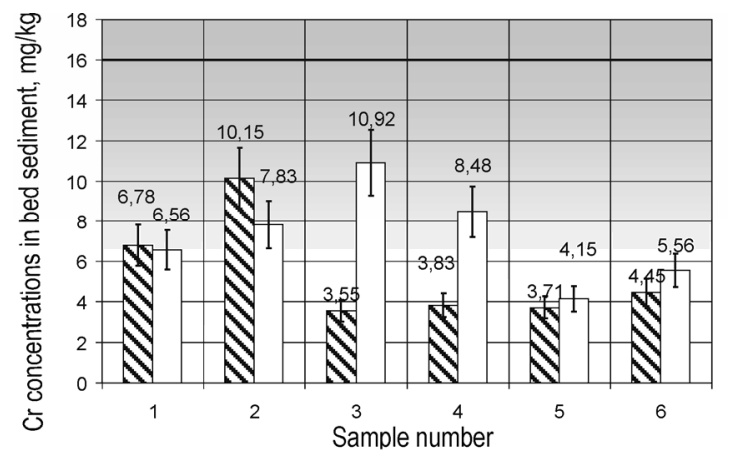

$\mathbf{\Delta}$ Concentrations of $\mathrm{Cr}$ in bed sediment of lakelets

$\square$ Concentrations of $\mathrm{Cr}$ in bed sediment of King Vilhelm Channel

- Background concentration of $\mathrm{Cr}$

Fig 10. Chromium concentrations in the bed sediment of surface waters in Kairiai Military Ground

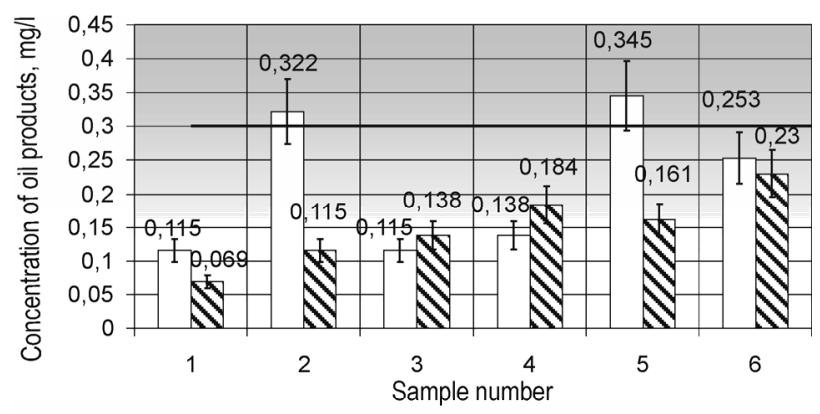

$\square$ Concentration of oil products in water of King Vilhelm
Channel
C Concentration of oil products in water of lakelets
- MAC of oil products in water

Fig 11. Oil product concentrations in the surface water bodies of Kairiai Military Ground
Medium determined concentration of lead was $69,21 \mathrm{mg} / \mathrm{kg}$ in the bed sediment of lakelets, and it was even $155,57 \mathrm{mg} / \mathrm{kg}$ in the bed sediment of King Vilhelm Channel. Background concentration of lead both in the soil and bed sediment is $15 \mathrm{mg} / \mathrm{kg}$, so it is obviuous that even minimum lead concentration is bigger than background. Medium determined lead concentrations in the bed sediment of lakelets and the Channel of King Vilhelm are respectively 4 and 10 times bigger than background. Maximum concentration of lead was detected in the samples taken from King Vilhelm Channel, and it was $458,65 \mathrm{mg} / \mathrm{kg}$, i e 21 time bigger than background. Such results show that the bed sediment of the investigated surface water bodies are especially polluted with lead compounds. As in the case of copper, lead compounds were not detected in the water of the investigated surface water bodies. It can be suggested that pollution has stopped at present, but in the past the water of lakelets and the Channel of King Vilhelm were continually polluted. Lead was the main compound of ammunition; it can be used for different alloys or explosives. At present in most cases lead is replaced by other, less toxic and dangeruous elements.

Chromium concentrations, determined in the bed sediment of surface water bodies in Kairiai Military Ground, were 2-3 times smaller than background (background concentration of chromium was $30,00 \mathrm{mg} / \mathrm{kg}$ ). Such results show that the bed sediment of surface water bodies situated or flowing through the territory of Kairiai Military Ground are not polluted with chromium compounds (Fig 10).

It is an answer to the question why pollution with lead has stopped even though the investigated territories are still intensively used for military needs.

Analysis of the 14 water samples taken in the territory of Kairiai Military Ground revealed that oil product concentrations varied from 0,069 to $0,345 \mathrm{mg} / \mathrm{l}$ (Fig 11). In 2 water samples taken from the Channel of King Vilhelm oil product concentrations were bigger than MAC $(0,3 \mathrm{mg} / \mathrm{l})$, regulated by the Norms of Hygiene of the Lithuanian Republic. Naturally oil products are not present in the environment, so it can be stated that the water of both lakelets and the Channel of King Vilhelm is polluted with oil products.

\section{Conclusions}

1. During the investigation copper, nickel and lead compounds were not detected in any sample taken from surface water bodies situated or flowing through the territory of Kairiai Military Ground.

2. Chromium compounds were detected only in the water of King Vilhelm Channel. Medium concentration of chromium was $0,00285 \mathrm{mg} / \mathrm{l}$, i e twice smaller than background. The water of lakelets and King Vilhelm Channel is not polluted with chromium.

3. During the investigation zinc compounds were found only in the water of lakelets in Kairiai Military Ground. Medium concentration of zinc was $0,248 \mathrm{mg} / \mathrm{l}$, i e 8 times bigger than background. The reason of pollution is military vehicle riding and washing. 
4. Manganese concentrations in samples taken from King Vilhelm Channel were in the range from 0,0092 to $0,0614 \mathrm{mg} / \mathrm{l}$, and medium manganese concentration was $0,032 \mathrm{mg} / \mathrm{kg}$, i e less than either background $(0,045 \mathrm{mg} / \mathrm{l})$ or MAC $(0,2 \mathrm{mg} / \mathrm{l})$. However, manganese concentrations in samples kvk2 and kvk5 exceeded the background limits.

5. Determined manganese concentrations in the water of lakelets were comparably big, ranging from $0,0253 \mathrm{mg} / \mathrm{l}$ to $0,0732 \mathrm{mg} / \mathrm{l}$. Medium manganese concentration in water of lakelets was $0,073 \mathrm{mg} / \mathrm{l}$, i e 1,6 time bigger than background $(0,045 \mathrm{mg} / \mathrm{l})$. The water of lakelets is polluted with manganese.

6. The investigation results show that the bed sediment of surface water bodies situated in the territory of Kairiai Military Ground are not polluted with manganese, zinc or chromium.

7. Copper, lead and partly zinc concentrations were not detected either in the water of King Vilhelm Channel or in the water of lakelets. The investigation results show that the investigated surface water bodies were polluted with copper, lead and zinc in the past, and pollutants accumulated in bed sediment.

8. Lead concentrations in the bed sediment of lakelets and King Vilhelm Channel varied from 26,89 to $458,65 \mathrm{mg} / \mathrm{kg}$. Even minimum determined lead concentration was bigger than background. Such results show that the bed sediment of the investigated surface water bodies are especially polluted with lead compounds.

9. In 2 water samples taken from King Vilhelm Channel oil product concentrations were bigger than MAC $(0,3 \mathrm{mg} / \mathrm{l})$. Naturally oil products are not present in the environment, so it can be stated that the water of both lakelets and King Vilhelm Channel is polluted with oil products.

\section{Literatūra}

1. Baubinas, R.; Taminskas, J. Karinè gamtonauda Lietuvoje sovietmečiu: ekologinès pasekmés. Vilnius, 1997-1998. $258 \mathrm{p}$.

2. Lubytė, J.; Matusevičius, K.; Eitminavičius, L. Lietuvos dirvožemių užterštumas radionuklidais. Iš: Konferencijos „Dirvotyros ir agrochemijos pasiekimai ir uždaviniai žemès reformos bei perejjimo ị rinkos ekonomiką metu" medžiaga. Kaunas, 1987, p 69-74.

3. Baltrènas, P.; Ignatavičius, G.; Vaišis, V. Pabradès centrinio poligono grunto užterštumo sunkiaisiais metalais tyrimai. Aplinkos inžinerija, IX t., Nr. 1, 2001, p 3-8.

4. Rifai, H. S.; Bedient, P. B.; Wilson, J. T.; Miller, K. M. and Armstrong, J. M. Biodegradation modelling at aviation fuel spill site. Journal of Environmental Engineering, Vol 117, No 5, p 1007-1030.

5. Achaz, Rudolf K. Invertebrates in risk assessment. Development of a test battery and of short term biotests for ecological risk assessment of soil. Journal of Soils \& Sediments, 2 (4), 2002, p 174-178.

6. Baltrenas, P.; Paliulis, D.; Vaišis, V. Naftos produktus sorbuojantis biosorbentas SPHAG-sorb. Aplinkos inžinerija, X t., Nr. 3, 2002, p 103-107.
7. DeBusk, W.; Graham, W.; Jacobs, J. et al. Determination of indicators of ecological change, 2001. http://www.ce.ufl.edu/ jjaw/Research/SERDP.htm

8. Pierznski, G. M.; Sims, J. T. and Vance, G. F. Soils and Environmental Quality. Lewis, Boca Raton, FL, 1993. $313 \mathrm{p}$.

9. Baltrènas, P.; Ignatavičius, G. Strategy of military lands reusing in Lithuania. Aproaches to the implementation of environment pollution prevention technologies at military bases. North Atlantic Treaty Organisation. In: Proceedings of the Symposium of the Rto studies, Analysis and Simulation Panel (SAS), Budapest, Hungary, 5-7 May 1999-2000, p 12-1, 12-8.

10. Idzelis, R. L.; Vaitiekūnas, P.; Survilaitè, O. Investigation and modelling of damage of landscape and its evaluation in military training grounds. In: Proceedings of the $6^{\text {th }}$ International Conference "Environmental Engineering", Vilnius, 2005, p 103-108.

11. Greičiùtè, K.; Vasarevičius, S. Investigation of the decrease of soil organic matter and soil pollution by heavy metals in areas intensively used for military activities. In: Proceedings of the Sixth Symposium and Exhibition „Environmental Contamination in Central and Eastern Europe and the Comonwealth of Independent States“, held in Prague, Czech Republic, 1-4 September 2003, p 527.

12. Балтренас, П.; Васарявичюс, С.; Грейчюте, К.; Вилутене, В. Влияние военных учений на состав и структуру почвы. Экология и промышленность России, 6, 2003, с. 36-40.

13. Vasarevičius, S.; Greičiūte, K. Investigation of soil pollution with heavy metals in Lithuanian military grounds. Journal of Environmental Engineering and Landscape Management, Vol XII, No 4, 2004, p 132-138.

14. Chapman, G.; Yudken, J. Briefing book on the miltary industrial complex. Council for a livable world education fund, Washington DC, 2000. 543 p.

15. Arms trade resource center. World Policy Institute, 2005. www.worldpolicy.org/projects/arms (revised on 20 Jan 2006).

16. Hoffman, D. Wastes of war. Russia's forgotten chemical weapons. Washington Post Foreign Service, Aug 16, 1998, 1 p.

17. Restoring degraded land. Energy and the environment. Federation of American Scientists, 2005. www.fas.org (revised on 15 Mar 2006).

18. Bradl, H. Heavy metals in the environment: origin, interaction and remediation, 6. Neubrucke: Academic press, 2005. 282 p.

19. New methods of cleaning up heavy metals in soils and water. Innovative solutions to an environmental problem. A HSRC Factsheet, 2003. http://www.cluin.org/ (revised on 20 Apr 2006).

20. Barthel, J.; Edwards, S. Chemical stabilization of heavy metals. In: Metals Treatment Technologies (MT2), Suite 3, 2004, p 151-162.

21. Bricka, R. M.; Teeter, C. D. C. Laboratory investigation of physical separation and chemical extraction treatment alternatives for soils collected from the old skeet range located at Fort Leavenworth, Kansas. Draft technical report IRRP-99, Vicksburg (MS): U.S. Army Engineer Waterways Experiment Station, 1999. 215 p.

22. Ernst, W. G. Earth systems processes and issues. Cambridge: Cambridge University Press, 2000. 566 p. 


\section{VANDENS TELKINIŲ UŽTARŠOS SUNKIAISIAIS METALAIS IR NAFTOS PRODUKTAIS KAIRIŲ KARINIAME POLIGONE TYRIMAI IR VERTINIMAS}

\section{R. L. Idzelis, K. Greičiūtė, D. Paliulis}

Santrauka

Paviršinio vandens bei jo telkinių dugno nuosėdų tarša sunkiaisiais metalais, nafta ir jos produktais - svarbi aplinkosaugos problema. Teršalai gali sklisti i aplinką garuodami ar migruodami gilyn ir užteršdami gruntinius vandenis. Nors yra žinoma, kad vienas iš karinès veiklos padariniu yra labai užteršti grunto plotai bei vanduo, tačiau vis dar stinga konkrečių duomenų apie tam tikrų teritorijų ruožų užterštumo lygi. Dar nèra pakankamai surinkta faktinès medžiagos apie karinių poligonų teritorijose daromą žalą ịvairiems aplinkos komponentams.

Šiame darbe įvertinta Kairių karinio poligono vandens telkinių užtarša sunkiaisiais metalais bei naftos produktais. Tyrimams parinktos būdingos vandens telkinių užtaršos vietos viename iš didžiausių - Kairių kariniame poligone. Tyrimo metu nustatyta Kairių poligono teritorijoje esančių paviršinio vandens telkinių ir jų dugno nuosèdų užtarša sunkiaisiais metalais bei vandens užtarša naftos produktais. Tyrimas leido atsakyti i esminius klausimus: kokie teršalai būdingi karinei veiklai naudojamiems vandens telkiniams, kokie yra užterštumo lygiai bei kurios vietos taršai jautriausios.

Reikšminiai žodžiai: kariniai poligonai, paviršinio vandens telkiniai, tarša, sunkieji metalai, naftos produktai, dugno nuosèdos.

\section{ИССЛЕДОВАНИЕ И ОЦЕНКА ЗАГРЯЗНЕННОСТИ ВОД ВОДОЕМОВ ТЯЖЕЛЫМИ МЕТАЛЛАМИ И НЕФТЕПРОДУКТАМИ НА ТЕРРИТОРИИ ВОЕННОГО ПОЛИГОНА В КАЙРЯЙ}

\section{Р.-Л. Идзялис, К. Грейчюте, Д. Палюлис}

Резюме

Загрязненность вод и осадков дна тяжелыми металлами, нефтью и ее продуктами - важная экологическая проблема. Загрязняющие вещества могут попасть в окружающую среду с выделяющимися из них газами или еще хуже - всасываются в почву, загрязняют грунтовые воды и таким образом могут попасть на территории, находящиеся далеко от источника загрязнения. Хотя уже давно известно, что одним из последствий военных действий являются сильно загрязненные поверхностные воды и почва, все еще не хватает конкретных данных об уровне загрязнения отдельных участков. Еще не собрано достаточно фактической информации о негативных факторах, которые испытывают отдельные компоненты окружающей среды на территориях военных полигонов.

В статье представлено исследование, которым была установлена загрязненность поверхностных вод на территории полигона в Кайряй тяжелыми металлами и нефтепродуктами, а также осадков дна тяжелыми металлами. Для исследования были подобраны типичные места на одном из самых больших полигонов Литвы - в Кайряй. Результаты исследования помогли ответить на вопрос о том, какие загрязняющие вещества в поверхностных водах, используемых для военных действий, встречаются чаще всего, какой степени достигло загрязнение, и т. п.

Ключевые слова: военные полигоны, поверхностные воды, загрязненность, тяжелые металлы, нефтепродукты, осадки дна.

Raimondas Leopoldas IDZELIS. Dr, Assoc Prof, Dept of Environmental Protection, Vilnius Gediminas Technical University (VGTU).

Doctor of Natural Sciences, 1993. Publications: author of more than 50 research papers, 1 study, co-author of 3 monographs. Research interests: ecology, landscape management, environmental protection.

Kristina GREIČIŪTĖ. Dr, junior research worker, Institute of Environmental Protection, Vilnius Gediminas Technical University (VGTU).

Doctor of Technological Sciences, VGTU, 2006. Master of Science (environmental engineering), VGTU, 2002. Publications: co-author of more than 12 research papers and 1 monograph. Research interests: negative impact of military activities on the soil, soil pollution with heavy metals, remediation technologies.

Dainius PALIULIS. Dr, Assoc Prof, Dept of Environmental Protection, Vilnius Gediminas Technical University (VGTU).

Doctor of Technological Sciences (air-cleaning devices), VGTU, 2000. Master of Science, Vilnius University (VU), 1996. Publications: co-author of more than 10 research papers. Research interests: air pollution, chemical pollutants of the environment, environmental chemistry. 